\title{
Biobibliometric portrait of B.K Sen: A librarian, information scientist and scientometrician
}

\author{
Bidyarthi Dutta \\ Department of Library and Information Science \\ Vidyasagar University, Midnapore 721102 \\ West Bengal, INDIA \\ e-mail: bidyarthi.bhaswati@gmail.com
}

\begin{abstract}
This biobibliometric study highlights the major aspects of the career of the Indian librarian and information scientist, Bimal Kanti Sen. As a professional librarian, he took major initiatives toenhance practical scientometric programs in India. He has contributed 390 writings since 1964 to 2018, i.e. over 55 years,including his service and retirement period. He authored seven writings per year on an average. Of the 390 writings, 184 are research articles, which means he contributed about three papers per year consistently over hisentire career period. Other than research articles, his contributions include technical and popular articles (55, 14\%), writings on terminology (48, 13\%), course materials $(37,10 \%)$, books $(12,3 \%)$, letters $(12,3 \%)$, book reviews $(9,2.5 \%)$, catalogue $(9$, $2.5 \%)$, review articles $(5,1.3 \%)$, reports $(5,1.3 \%)$ and bibliographies $(4,1 \%)$. The year-wise distribution of authorship pattern, collaborative authors and degree of collaboration, author productivity, core journals and highly cited publications are identified in this paper. Different academic indicators of Bimal Kanti Sen are calculated on the basis of citation data available from Web of Science, Scopus and Google Scholar. His academic and research activitiessteadily increased with his age. His most notable research work was normalization of the Impact Factor and identifying Impact Factor of non-SCI journal. His other notable works include biobibliometric analysis, history of science, lexicography, etc. He is still academically active and continues to add to the knowledge repository.
\end{abstract}

Keywords: Biobibliometrics; Bibliometric profile; Bimal Kanti Sen; B K Sen;Impact Factor Normalization

\section{INTRODUCTION}

Scientometrics is a domain that is devoted to quantitative studies of science and technology. It aims at the advancement of knowledge in the course of science andtechnologydevelopment, emphasizingthe context of sociological and policy-related questions. A special weightage is giventothe role of quantitative analysis. Various other synonymous terms hover around the term scientometrics, i.e. bibliometrics, informetrics, webometrics, cybermetrics, etc. Scientific publications seem to have provided the best available basis for measuring the outputs of individual scientists as there is a good correlation between the eminence of scientists and their sustained scholarly publications (Hertzel and Price 1986; 1987). Scientometric studies are highly valued by historians of science, biographers of scientists, administrators of scientific establishments, science policy makers, research and development managers, educationalists, scientometricians, young scientists, documentalists, information scientists and science journalists (Stockley 1957). 
Biobibliometrics deals with the biographical study of the individual careers of scientists and researchers and correlating bibliographic analysis of publications or academic and scientific achievements. Individuals create ideas. Institutions are built by individuals and grow around individuals, which are the basic foundations of any institution. The probable doyens of any subject domain may be predicted by studying the core individuals of the same. Biobibliometrics is a term that was first coined by Sen and Gan (1990) to mean the quantitative and analytical method for discovering and establishing functional relationships between biodata and biblio-data elements. There are many biobibliometric studies, but they have hardly used the term 'biobibliometrics' in the titles of the papers except for Sen and Gan (1990) and Tiew (1999).

Kalyane and Kalyane (1993) first used the phrase 'scientometric portrait' to carry out biobibliometric studies on scientists. In some of the papers, Kalyane and Devarai (1994) and Kalyane and Samanta (1995), used the term 'informetrics' in the titles of their papers on C. S. Vekata Ram and K. Ramiah respectively. However, there was a continuous use of the phrase 'scientometric portrait' (Kalyane and Kalyane 1993; Kalyane and Kalyane 1994; Kademani and Kalyane 1994; Kademani and Kalyane 1994; Kalyane 1995; Kalyane and Kademani 1995, Kalyane and Munnolli 1995; Kalyane and Sen 1996; Kademani, Kalyane and Kademani 1996; Kademani and Kalyane 1996; Kalyane and Kademani 1997; Kalyane and Sen 1998; Kademani and Kalyane 1998; Kademani, Kalyane and Jange 1999; Kademani, Kalyane and Kumar 2000; Kademani, Kalyane and Kumar 2001; Kalyane, Prakasan and Kumar 2001; Kalyane, Prakasan and Vijay Kumar 2002; , Kalyane and Kumar 2002; , Kalyane and Kumar 2002; Koganuraman et al. 2004; Angadi et al. 2004; Kademani et al. 2005) consistently.A comprehensive reference list on biobibliometric studies is provided by Koley and Sen(2018). The biobibliometric studies or scientometric portrait development carried out by Amsan, Angadi, Balakrishnan, Devarai, Hazarika, Kalyane, Kademani, Karanjai, Koganuramath, Koley, Kumar, Mallikarjun, Mohan, Munnolli, Muttayya, Narayana, Prakashan, Samanta, Sangam, Sarme, Savanur, Sen, Suresh, Vellaichamy and Tiew, illustrates scientists from different subject domains as listed in Table 1. Besides the group headed by Kalyane, some other biobibliometric studies were carried out by Sangam et al $(2006,2007,2010)$. The first biobibliometric study on a film actress, Suchitra Sen, and on a biobibliometrician, Sambhu Nath De were carried out by Koley and Sen (2014a; 2016b), who also conducted a few other biobibliometric studies (Koley and Sen 2014b; 2016a). An inspection of Table 1 instantly reveals that the practical biobibliometrics works started in 1993, while the theoretical concept was introduced by Sen and Gan in 1990. In all, the scientometric portraits of 43 scientists were developed by Kalyane et al. Of the 43 scientists, 26 were of Indian scientists, followed by 4 scientists each from UK and USA, while another 2 were from Germany. The native countries of other scientists include Egypt, France, Hungary, Malaysia, Netherlands and Scotland (one scientist each). The scientists from Physics and Astrophysics top the list (13, Nobel-Laureate: 5) followed by Chemistry and Biology (7 each, Nobel-Laureate: 3 in Chemistry), Physiology/ Medicine (7, Nobel-Laureate: 2) and Scientometrics (4). The scientometric portraits developed for laureate scientists figures ten, with five from Physics. The Physics and Astrophysics areas are found to be the most favourable for the biobibliometricians. The distinguished scientometricians with biobibliometric studiesinclude Eugene Garfield, Tibor Braun and Mike Thelwall. Notably Tibor Braun was a chemist originally, while Eugene Garfield was proclaimed as a historian of science. The focal area of Mike Thelwall is altmetric studies rather than traditional scientometrics and bibliometrics.To date only one Indian scientometrician, V.L. Kalyane,biobibliometric portrait was developed. But Kalyane is better known as biobibliometrician rather than a general scientometrician or bibliometrician. This paper is the first attempt to present abiobibliometric study of a multifaceted Indian scholarBimal Kanti Sen or more well known as B.K. Sen, who was a 
librarian atthe National Science Library of India over a substantive time, and proclaimed as aninformation scientist, ascientometrician and a lexicographer.

Table 1: List of Scientists with Biobibliometric and Scientometric Portraits

\begin{tabular}{|c|c|c|c|c|}
\hline No. & Subject & Year & Name of the Scientist & Nationality \\
\hline 1 & Physiology/ Medicine & 1993 & Vinodini Reddy & India \\
\hline 2 & Mathematics & 1994 & C. S. Venkataraman & India \\
\hline 3 & Physics & 1994 & P K lyenger & India \\
\hline 4 & Physics & 1994 & C. V. Raman (Nobel Laureate) & India \\
\hline 5 & Biology/ Life Science & 1994 & M. S. Swaminathan & India \\
\hline 6 & Physics-Nuclear & 1995 & R. Chidambaram & India \\
\hline 7 & Chemistry & 1995 & T. S. West & Scottland \\
\hline 8 & Biology/ Life Science & 1995 & P. M. Bhargava & India \\
\hline 9 & Agricultural Science & 1995 & K Ramaiah & India \\
\hline 10 & Astrophysics & 1996 & S. Chandrasekhar (Nobel Laureate) & India \\
\hline 11 & Physics & 1996 & Pierre-Gilles de Gennes (Nobel Laureate) & France \\
\hline 12 & Physics & 1996 & K. S. Krishnan & India \\
\hline 13 & Physiology/ Medicine & 1997 & Barbara McClintock (Nobel Laureate) & USA \\
\hline 14 & Biology-Genetics & 1998 & C. R. Bhatia & India \\
\hline 15 & Chemistry & 1999 & $\begin{array}{l}\text { Dorothy Crowfoot Hodgkin (Nobel } \\
\text { Laureate) }\end{array}$ & UK \\
\hline 16 & History-Malaysia & 1999 & K. K. Kim & Malaysia \\
\hline 17 & Astrophysics & 2000 & Vikram Ambalal Sarabhai & India \\
\hline 18 & Chemistry & 2001 & Ahmed Hassan Zewail (Nobel Laureate) & Egypt \\
\hline 19 & Biology-Molecular Biology & 2001 & Ranjit Kumar Mitra & India \\
\hline 20 & Chemistry & 2002 & Harold W Kroto (Nobel Laureate) & UK \\
\hline 21 & Astrophysics & 2003 & R. G. Rastogi & India \\
\hline 22 & Chemistry + Scientometrics & 2003 & Tibor Braun & Hungary \\
\hline 23 & Chemistry-Physical & 2003 & Biman Bagchi & India \\
\hline 24 & Physics & 2004 & Wolfgang Ketterle (Nobel Laureate) & Germany \\
\hline 25 & Physics-Nuclear & 2004 & Homi J. Bhabha & India \\
\hline 26 & Botany & 2004 & L. L. Narayana & India \\
\hline 27 & Physiology/ Medicine & 2004 & H. Hartwell (Nobel Laureate) & USA \\
\hline 28 & Mathematics & 2006 & N. Rudraiah & India \\
\hline 29 & Physics & 2006 & Anthony J. Leggett (Nobel Laureate) & USA \\
\hline 30 & Earth Science & 2006 & Peter John Wyllie & UK \\
\hline 31 & Physiology/ Medicine & 2006 & B. N. Koley & India \\
\hline 32 & Physics & 2007 & Sivaraj Ramaseshan & India \\
\hline 33 & Chemistry-Polymer Science & 2008 & T. M. Aminabhavi & India \\
\hline 34 & Physiology/ Medicine & 2008 & T. M. Aminabhavi & India \\
\hline 35 & Scientometrics, History of Science & 2010 & Eugene Garfield & USA \\
\hline 36 & Bio-meteorology & 2010 & Nayana Nandu Borthakur & India \\
\hline 37 & Virology & 2011 & Harald Zur Hausen & Germany \\
\hline 38 & Physiology/ Medicine & 2014 & Sambhunath De & India \\
\hline 39 & Bengalee film actress & 2014 & Suchitra Sen & India \\
\hline 40 & Scientometrics and Altmetrics & 2016 & Mike Thelwall & UK \\
\hline 41 & Scientometrics, Biobibliometrics & 2016 & V. L. Kalyane & India \\
\hline 42 & Physiology/ Medicine & 2016 & A. S. Paintal & India \\
\hline 43 & Astrophysics & 2018 & J. H. Oort & Netherlands \\
\hline
\end{tabular}


This biobibliometric study includes productivity, collaboration and authorship pattern study and scientometric indicator analysis of Bimal Kanti Sen, a former scientist of the Indian National Scientific Documentation Centre or INSDOC (now called National Institute of Science Communication and Information Resources, NISCAIR). He also served at the University of Malaya, Malaysia for five years (1995-1999) as a Visiting Professor.

\section{BRIEF BIOGRAPHICAL SKETCH}

B.K. Sen was born $2^{\text {nd }}$ August 1938, at Charmadhua, P.O. Chandrakona, Dist - Mymensingh, Bengal, India (now in Bangladesh). He is the fourth son of Mr. Benode Bihari Sen and Ms. Haima Bala Sen.He was admitted to Charmadhua Government Primary School where he studied up to Class IV and obtained a scholarship through a competitive examination. Thereafter, he joined Chandrakona Rajlakshmi High School and studied up to Class VI. Throughout his schooling, he was the top students of his class. While in Class VII, a riot broke out in East Pakistan which forced his family to leave their home practically empty handed to settle in a village called Hansdaha near Gulab Bag in the district ofPurnea in Bihar. Here he was admitted into Purnia Zila School which was four miles away from the village. Everyday he walked barefooted for eight miles to attend school. The distance of the school, the Hindi medium and lack of books due to utter poverty culminated in his becoming an academically average student. He passed his secondary examination in second division. For a short time he was admitted toRampurhat College to study Intermediate in Science. He had to leave the college again due to financial constraints. His education would have found a dead end here had his maternal uncle, Dhirendra Chandra Chanda, not come forward to provide him boarding and lodging in his house at Belgharia in Kolkata. In the City College of Amherst Street, Calcutta, Prof. Manoranjan Dasgupta (the then Vice Principal of the College) was kind enough to give him admission in Intermediate in Science after the date of admission was long over. He then completed his bachelor's degree in Science with Distinction. Hereafter, he joined the West Bengal Government Service in 1960 as a Lower Division Assistant. While working here he used to walk everyday along Bowbazar Street up to Writers Building to do his duty, and encountered the signboard of Bengal Library Association (BLA) located at Huzury Mall Lane, of Bowbazar Street, Calcutta. In his early childhood he has seen a small collection of books in his home belonging to his father. The books were used to primarily answer the various queries of the villagers, such as the auspicious day for a journey, the days of various festivals, full moon and new moon, and so on. This developed in him a love for books. Possibly, his love for books one day landed him in BLA's office where from he completed his Certificate Course in Library Science. He obtained his library science degree from the University of Calcutta. He was a Gold Medallist for the Master in Library and Information Science from University of Delhi. His PhD was awarded by Jadavpur University in 1995 for his thesis entitled Indian Scientific Periodicals: A Study of the Origin and Development up to 1900 under the supervision of Prof. Prabir Roychowdhury. This study added yet another area, i.e. History of science, into his research career.

He started his professional career as aLibrary Assistant in the Finance Department Library, Government of West Bengal, in 1961. This duty he performed besides his duty as a Lower Division Assistant (LDA.) Then he joined as a Junior Documentation Assistant, at INSDOC, New Delhi in 1963, where he served upto 1995. During his career of 32 years he worked in various departments and headed successively the Russian Science Information Centre, National Centre on Bibliometrics, Education and Training Division, and finally National Science Library. He left INSDOC in 1995 tojoin University of Malaya in Malaysia as visiting professor where he served upto 1999 . Here he contributed substantially to the development 
of the Master of Library and Information Science (MLIS) programme. He also was part of the team who initiated and contributed to the very first issue of the Malaysian Journal of Library \& Information Science, an international journal. It may be noted that this was the first LIS journal from Asia to be indexed by Web of Science. In INSDOC, he shouldered the full responsibility of the Education and Training Division during 1988-1995. He taught for a period of 25 years, mainly in subjects relating to Information Sources, Classification, and Information and Society in the Associateship in Information Science (AISc) Course. He organized numerous courses of 4-week duration devoted to Computer Application in Library and Information Activities; and also organized four 10-day training courses on Bibliometrics to train librarians and information specialists from all over India, under the auspices of the National Centre on Bibliometrics, a NISSAT project.He organised three courses of one-week duration on CDS/ISIS to train about 70 INSDOC employees in June/July 1988. Heprepared around 30 course materials for BLIS, MLIS, M Phil/PhD courses in1989 at the School of Social Sciences, Indira Gandhi National Open University (IGNOU), New Delhi.

Prof. Sen is actively associated with the Delhi Library Association. He taught Reference Service to Diploma students for about five years during 1970s. He also taught Cataloguing (Theory) to the Certificate Course students for about 20 years during 1975 to 1995 . He delivered numerous visiting lectures at the North Eastern Hill University, Shillong; Aligarh Muslim University, Aligarh; Dr. Hari Singh Gaur University, Sagar; Jamia Milia Islamia, New Delhi; Technical Teachers Training Institute, Chandigarh; State Council of Educational Research and Training, New Delhi; National Institute of Oceanography, Goa; Annamalai University, Regional Study Centre, New Delhi; University of Burdwan, Bardhaman; Jadavpur University, Kolkata; Vidyasagar University, Midnapore; and Mizoram University, Aizawl on diverse topics such as Reference Service, Abstracting and Indexing Services, Bibliometrics, Information Science, Information Centre Management and Universal Decimal Classification. He delivered several lectures on Energy Information Handling in Nepal in 1987, and in Pakistan in 1991 at the National Workshop on Energy Information Handling organised at Kathmandu and Islamabad respectively under the auspices of INNERTAP, UNESCO. Apart from teaching, he has been distinctly involved in several other areas such as, editing, compilation of reference sources; writing of course materials; compilation of scientific glossaries; research in bibliometrics and related areas; research in history of science; popular science writing; and writing of poems.

\section{RESEARCH CONTRIBUTIONS}

During his tenure in INSDOC (now NISCAIR), and as visiting Professor in universities around India and abroad, most of his research activities were confined to bibliometric studies, scientific periodicals, scientific societies and lexicography. More specifically the research domains may be categorised as:

(a) History of Indian Science and Technology (S\& T) periodicals

(b) History of Indian scientific societies

(c) Determination of impact factors of journals not covered by Science Citation Index

(d) Development of the concept of normalized impact factor of S \& T periodicals

(e) Evaluation of recent scientific output of laboratories using bibliometric methods

(f) Coverage of Indian S \& T literature by international abstracting and indexingServices

(g) S \& T terminology in Bengali and lexicography

The research output of the Council of Scientific and Industrial Research (CSIR) is being analyzed using the method of evaluation developed by Prof. Sen since 1986. Scientists are 
being ranked for the award of prestigious prizes and fellowships based on this analysis. The analysis has generated numerous useful indicators for science management and attracted the attention of many top ranking scientists of India. Dr Eugene Garfield termed the method of determination of the impact factor of non-SCI journals as an effective method. In INSDOC, Prof. Sen established The National Centre on Bibliometrics through the financial support of NISSAT (National Information System on Science and Technology), Government of India. The Centre is the first of its kind in Asia. He prepared the research project proposal, along with acquiring of funds, selection of people, planning of the services etc. to run the Centre.The Centre is operational since 1988. Under the auspices of the centre, a publication titled In Search of Knowledge was published in six volumes, incorporating significant contributions of CSIR scientists published since 1942. CSIR Research Output - a Bibliometric Analysis for the years 1986, 1987, 1988, 1989, 1990, 1991 were also publishedby the Centre under Prof. Sen's supervision. This publication created a great impact in CSIR since it became a mirror of the achievements of various CSIR laboratories. Another big contribution of the Centre is the evaluation of the contributions of a scientist based on the citations received by his papers. The method developed by the Centre has found wide application in India for the purpose of awarding a scientist or electing him/her as a fellow of a prestigious academy of science. Citation analysis has become a common term among the Indian scientists today. Prof. Sen may be reckoned as the Father of citation analysis in India. He carried out bibliometric evaluation of some 20 departments of Indian universities at the behest of the University Grants Commission, India. He is a veteran editor during the last forty years of various primary and secondary journals, directories, monographs, reports, etc. Some of the publications edited by him are listed below:

(a) Indian Educational Material - an Annotated Quarterly Bibliography. [Associate Editor 1966-1970]

(b) Contents List of Soviet Scientific Periodicals [Editor 1971-1980]

(c) iRussian Scientific and Technical Publications - An Accession List [ Editor 1971-1980]

(d) Annals of Library Science and Documentation [Associate Editor 1981-1987; Editor 1988-1989]

(e) Malaysian Journal of Computer Science [Editorial board 1995-1999]

(f) Malaysian Journal of Library \& Information Science [Editor 1995-1999]

(g) ILA Bulletin [Editor 2000-2001]

(h) Information Today and Tomorrow [Editor 1999 -2002]

(i) Directory of Scientific Research Institutions in India. $2^{\text {nd }}$ edition.

(j) Open Access to Knowledge and Information - Scholarly Literature and Digital Library Initiatives - The South Asian Scenario/ Anup Kumar Das(UNESCO publication);

(k) Digital Archiving of Audio Content (UNESCO publication)

(I) Report of the National Forest Commission

(m) Voices from the Field. 2011. (ICFRE Publication)

(n) Organizing knowledge: then and now. Bidyarthi Dutta; (New Delhi: Ess Ess Pub. 2015.)

He played the leading role in setting up of the Russian Science Information Centre in INSDOC in 1971. The overall organisation, planning, and management of the Centre was conducted by him for about ten years. The two serials producedby him for disseminating information on Russian books and periodical articles on science and technology are: Russian Scientific \& Technical Publication- an Accession List; and Contents List of Soviet Scientific Periodicals. Every detail of the serials including their contents, organisation of inside matter, index etc. was worked out by him as the Editor of the two serials. The Express Information Service was introduced in India for the first time by him in 1973 when a serial publication on metallurgy providing long digests of articles was published. The Information Letter Service, 
a novel current awareness service, was also introduced by him for the first time in India soon after the establishment of the Centre.

Prof. Sen is also actively involved in developing subject dictionaries and glossaries during the last fifty years. He compiled many subject glossaries on Physics, Chemistry, Library \& Information Science etc. He published over 160 research articles in various national and international journals. He received many distinguished awards, i.e. Prof. S Dasgupta Memorial Gold Medal from University of Delhi in 1983; Dr. T M Das Foundation Award for the Best Science Writing in Jnan Bichitra in 1994; Tincori Dutt Award for Best Writing in Library and Information Science published in Granthagar from Bengal Library Association in 1998 and Distinguished Leadership Award by American Biographical Institute in 1997.

\section{Scope}

Scientometric portrait study is a quantitative analysis of the publications of an author or a scientist, either living or dead. It concludes all publications during one's life time. The present study is confined to 380 publication contributions of B.K. Senthat include research articles published in various national and international journals, conference proceedings, books, technical and popular articles, review articles, bibliographies, course materials, reports, letters and catalogues, etc. during 1964-2018.

\section{OBJECTIVES}

The main objectives of the study are:

(a) To ascertain the growth pattern of research and other contributions of B K Sen;

(b) Toidentify the year-wise distribution of authorship pattern;

(c) To identify the collaborative authors and degree of collaboration;

(d) To calculate author productivity;

(e) To identify core journals;

(f) To identify highlycited publications;

(g) Toidentifydifferent academic indicators of B K Sen

\section{METHOD}

Publications count and analysis is one of the bibliometric/scientometric analytic technique. It involves studying the number of publications of a single author, or productivity of literature in the field, with the purpose to compare the amount of research in different countries, and the amount produced during different periods or in different subdivisions of the field (Hertzel 1987). Using the same technique, thisstudy reports on a single author study of'B. K. Sen'. Scientific publications seem to provide the best available basis for measuring the research output. The citation data for this study was obtained from Scopus, Web of Science and Google Scholar databases to extract relevant data on B. K. Sen over the period of fifty four years (1964-2018). In total, 380 publication contributions of B. K. Senwere identified for this study. The collected data were transferred into Microsoft Excel 2010, and subjected to further analysis to meet the objectives of the study. 
Dutta, $B$.

\section{DATA ANALYSIS}

\section{Growth of Publications}

The yearwise variations of cumulative number of research article publications and authorship pattern analysis are presented in Table 2 . The single-authored journal articles by B K Sen are 73, while multi-authored articles are 111. Of the 111 multi-authored publications, Sen was the first author in 29 articles, second author in 55 articles and third author in 25 articles. The CAPC varies with PPA in accordance with the equation: $y=0.0189 * x^{2.298}$, where, $X=$ PPA and $Y=$ CAPC (Figure 1 ). This is a non-linear polynomial equation where ' $y$ ' represents nearly parabolic pattern. The growth of publications other than journal articles are presented in Table 3.

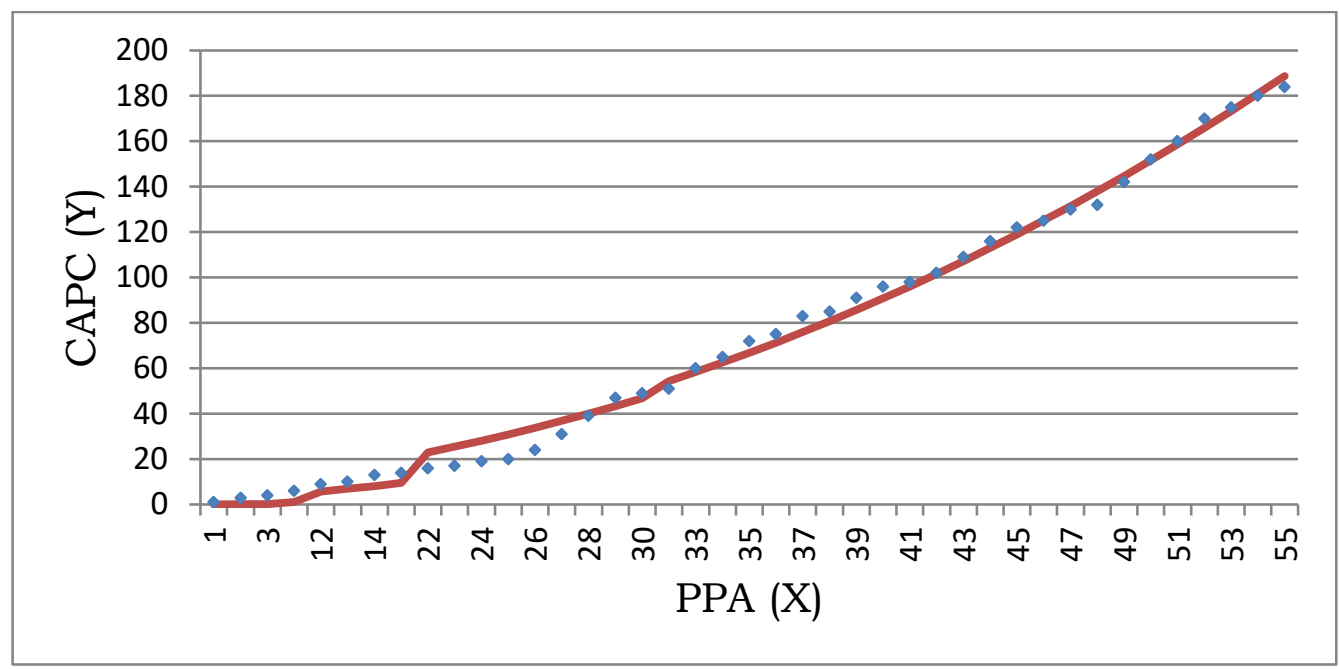

Figure 1: Variation of CAPC with PPA for Journal Articles

The CAPC varies with PPA in accordance with the equation: $y=3.95 * x-4.54$, (Figure 2), where, $x=P P A$ and $y=C A P C$. This is a linear equation with the values of slope and intercept are 3.95 and $(-4.54)$ respectively. The growth of all publications is shown in Table 4. The CAPC varies with PPA in accordance with the equation: $y=1.638^{*} x^{1.361}$, where, $x=$ PPA and $y=C A P C$. This is a non-linear polynomial equation (Figure 3 ).

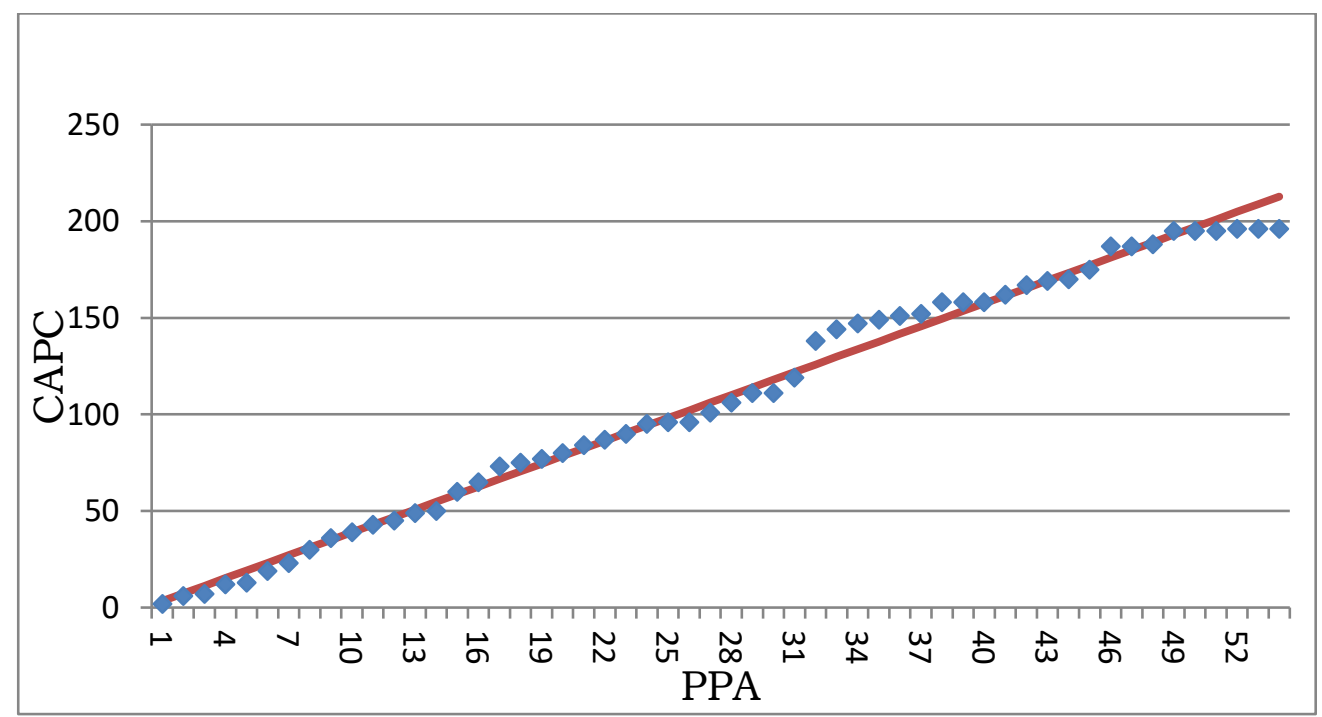

Figure 2: Variation of CAPC with PPA for publications other than journal articles 
Table 2: B.K.Sen's Growth of Research Articles and Authorship Pattern

\begin{tabular}{|c|c|c|c|c|c|c|c|c|c|c|c|c|c|}
\hline 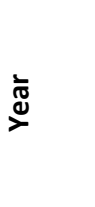 & ù & 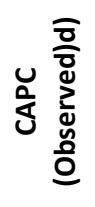 & u & $\varangle$ & 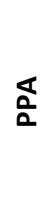 & $\frac{a}{s}$ & $\sum_{\Sigma}^{\frac{0}{\alpha}}$ & 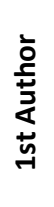 & 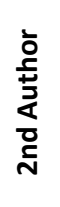 & 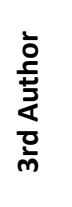 & 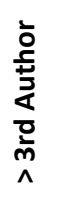 & 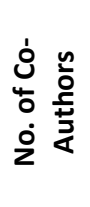 & 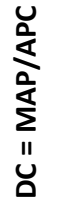 \\
\hline 1964 & 1 & 1 & 2.04 & 26 & 1 & & 1 & & 1 & & & 1 & 1.00 \\
\hline 1965 & 2 & 3 & 2.38 & 27 & 2 & & 2 & & 2 & & & 3 & 1.00 \\
\hline 1966 & 1 & 4 & 2.77 & 28 & 3 & & 1 & 1 & & & & 1 & 1.00 \\
\hline 1969 & 2 & 6 & 4.19 & 31 & 6 & 2 & & & & & & & 0.00 \\
\hline 1975 & 3 & 9 & 8.65 & 37 & 12 & & 3 & 1 & 2 & & & 4 & 1.00 \\
\hline 1976 & 1 & 10 & 9.65 & 38 & 13 & & 1 & & & & 1 & 3 & 1.00 \\
\hline 1977 & 3 & 13 & 10.73 & 39 & 14 & & 3 & & 3 & & & 2 & 1.00 \\
\hline 1978 & 1 & 14 & 11.91 & 40 & 15 & 1 & & & & & & & 0.00 \\
\hline 1985 & 2 & 16 & 23.04 & 47 & 22 & 1 & 1 & & 1 & & & 1 & 0.50 \\
\hline 1986 & 1 & 17 & 25.11 & 48 & 23 & & 1 & & 1 & & & 1 & 1.00 \\
\hline 1987 & 2 & 19 & 27.32 & 49 & 24 & 2 & & & & & & & 0.00 \\
\hline 1988 & 1 & 20 & 29.68 & 50 & 25 & 1 & & & & & & & 0.00 \\
\hline 1989 & 4 & 24 & 32.18 & 51 & 26 & & 4 & 4 & & & & 3 & 1.00 \\
\hline 1990 & 7 & 31 & 34.84 & 52 & 27 & 2 & 5 & 4 & 1 & & & 3 & 0.71 \\
\hline 1991 & 8 & 39 & 37.67 & 53 & 28 & 5 & 3 & & 2 & 1 & & 4 & 0.38 \\
\hline 1992 & 8 & 47 & 40.66 & 54 & 29 & 1 & 7 & 4 & 1 & 2 & & 6 & 0.88 \\
\hline 1993 & 2 & 49 & 43.83 & 55 & 30 & & 2 & 2 & & & & 2 & 1.00 \\
\hline 1995 & 2 & 51 & 50.74 & 57 & 32 & & 2 & 1 & 1 & & & 2 & 1.00 \\
\hline 1996 & 9 & 60 & 54.48 & 58 & 33 & 3 & 6 & 3 & 1 & 2 & & 7 & 0.67 \\
\hline 1997 & 5 & 65 & 58.43 & 59 & 34 & 3 & 2 & & 1 & & 1 & 4 & 0.40 \\
\hline 1998 & 7 & 72 & 62.59 & 60 & 35 & 3 & 4 & 3 & 1 & & & 9 & 0.57 \\
\hline 1999 & 3 & 75 & 66.97 & 61 & 36 & 2 & 1 & & 1 & & & 1 & 0.33 \\
\hline 2000 & 8 & 83 & 71.58 & 62 & 37 & 3 & 5 & & 5 & & & 2 & 0.63 \\
\hline 2001 & 2 & 85 & 76.42 & 63 & 38 & & 2 & 1 & & 1 & & 3 & 1.00 \\
\hline 2002 & 6 & 91 & 81.51 & 64 & 39 & & 6 & 3 & 1 & 2 & & 3 & 1.00 \\
\hline 2003 & 5 & 96 & 86.85 & 65 & 40 & & 5 & 2 & 2 & 1 & & 5 & 1.00 \\
\hline 2004 & 2 & 98 & 92.45 & 66 & 41 & 2 & & & & & & & 0.00 \\
\hline 2005 & 4 & 102 & 98.32 & 67 & 42 & & 4 & & 3 & 1 & & 5 & 1.00 \\
\hline 2006 & 7 & 109 & 104.47 & 68 & 43 & 2 & 5 & & 3 & 2 & & 5 & 0.71 \\
\hline 2007 & 7 & 116 & 110.90 & 69 & 44 & 3 & 4 & & 1 & 3 & & 6 & 0.57 \\
\hline 2008 & 6 & 122 & 117.63 & 70 & 45 & 3 & 3 & & 2 & 1 & & 5 & 0.50 \\
\hline 2009 & 3 & 125 & 124.66 & 71 & 46 & 2 & 1 & & & 1 & & 2 & 0.33 \\
\hline 2010 & 5 & 130 & 132.00 & 72 & 47 & 3 & 2 & & & 2 & & 4 & 0.40 \\
\hline 2011 & 2 & 132 & 139.67 & 73 & 48 & 1 & 1 & & 1 & & & 1 & 0.50 \\
\hline 2012 & 10 & 142 & 147.67 & 74 & 49 & 5 & 5 & & 3 & 2 & & 4 & 0.50 \\
\hline 2013 & 10 & 152 & 156.01 & 75 & 50 & 6 & 4 & & 3 & 1 & & 6 & 0.40 \\
\hline 2014 & 8 & 160 & 164.70 & 76 & 51 & 4 & 4 & & 3 & 1 & & 4 & 0.50 \\
\hline 2015 & 10 & 170 & 173.75 & 77 & 52 & 5 & 5 & & 3 & 2 & & 8 & 0.50 \\
\hline 2016 & 5 & 175 & 183.17 & 78 & 53 & 1 & 4 & & 4 & & & 3 & 0.80 \\
\hline 2017 & 5 & 180 & 192.98 & 79 & 54 & 4 & 1 & & 1 & & & 1 & 0.20 \\
\hline 2018 & 4 & 184 & 203.17 & 80 & 55 & 3 & 1 & & 1 & & & 1 & 0.25 \\
\hline All & 184 & & & & & 73 & 111 & 29 & 55 & 25 & 2 & 125 & \\
\hline
\end{tabular}

[APC=Annual Publication Count; CAPC=Cumulative Annual Publication Count; AA=Author's Age; $P P A=$ Publication Productivity Age; $D C=$ Degree of Collaboration; MAP=Multi-Authored Publications; $S A P=$ Single-Authored Publications] 
Dutta, B.

Table 3: Growth of Publications other than Research Articles

\begin{tabular}{|c|c|c|c|c|c|c|c|c|c|c|c|c|c|c|c|}
\hline$\stackrel{\text { む }}{\stackrel{\nu}{\nu}}$ & 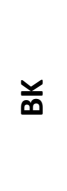 & $\underset{d x}{\overleftarrow{x}}$ & $\leftleftarrows$ & 々 & 呂 & $\sqsubseteq$ & $\vec{\infty}$ & $ち$ & $\sum_{U}$ & $\stackrel{\hat{x}}{\underline{x}}$ & 这 & $\varangle$ & 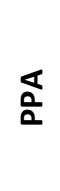 & 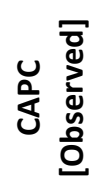 & 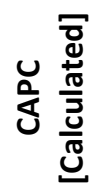 \\
\hline 1965 & & 1 & & & & & & 1 & & & 2 & 27 & 2 & 2 & 2.65 \\
\hline 1966 & & & 1 & & & & 1 & 2 & & & 4 & 28 & 3 & 6 & 6.6 \\
\hline 1967 & & & & & & & & 1 & & & 1 & 29 & 4 & 7 & 10.6 \\
\hline 1968 & & & 1 & & & 1 & & 3 & & & 5 & 30 & 5 & 12 & 14.5 \\
\hline 1969 & & & & & & & & 1 & & & 1 & 31 & 6 & 13 & 18.5 \\
\hline 1970 & & & 5 & & & & 1 & & & & 6 & 32 & 7 & 19 & 22.4 \\
\hline 1971 & & & 2 & 1 & & & & 1 & & & 4 & 33 & 8 & 23 & 26.4 \\
\hline 1972 & & & 5 & 1 & & & 1 & & & & 7 & 34 & 9 & 30 & 30.3 \\
\hline 1973 & & 1 & 2 & 1 & 1 & & & & & 1 & 6 & 35 & 10 & 36 & 34.3 \\
\hline 1974 & & & 2 & & 1 & & & & & & 3 & 36 & 11 & 39 & 38.2 \\
\hline 1975 & & & 2 & & & & & & 2 & & 4 & 37 & 12 & 43 & 42.2 \\
\hline 1976 & & & 1 & 1 & & & & & & & 2 & 38 & 13 & 45 & 46.1 \\
\hline 1977 & & & & 2 & 2 & & & & & & 4 & 39 & 14 & 49 & 50.1 \\
\hline 1978 & & & & 1 & & & & & & & 1 & 40 & 15 & 50 & 54 \\
\hline 1979 & & & 5 & 3 & 2 & & & & & & 10 & 41 & 16 & 60 & 58 \\
\hline 1980 & & & 3 & & & 2 & & & & & 5 & 42 & 17 & 65 & 61.9 \\
\hline 1981 & & 1 & 1 & 2 & & 3 & 1 & & & & 8 & 43 & 18 & 73 & 65.9 \\
\hline 1982 & & & & 2 & & & & & & & 2 & 44 & 19 & 75 & 69.8 \\
\hline 1983 & & & & 1 & & & & & & 1 & 2 & 45 & 20 & 77 & 73.8 \\
\hline 1984 & & & 2 & 1 & & & & & & & 3 & 46 & 21 & 80 & 77.7 \\
\hline 1985 & 2 & & & 1 & 1 & & & & & & 4 & 47 & 22 & 84 & 81.7 \\
\hline 1986 & & 1 & 2 & & & & & & & & 3 & 48 & 23 & 87 & 85.6 \\
\hline 1987 & & & 1 & & & & & & 1 & 1 & 3 & 49 & 24 & 90 & 89.6 \\
\hline 1988 & 2 & & 1 & & & & & & 2 & & 5 & 50 & 25 & 95 & 93.5 \\
\hline 1989 & 1 & & & & & & & & & & 1 & 51 & 26 & 96 & 97.5 \\
\hline 1990 & & & & & & & & & & & 0 & 52 & 27 & 96 & 101 \\
\hline 1991 & & 1 & & & & 2 & & & 1 & 1 & 5 & 53 & 28 & 101 & 105 \\
\hline 1992 & & & 1 & 1 & & & & & 3 & & 5 & 54 & 29 & 106 & 109 \\
\hline 1993 & & & & & 1 & & & & 3 & 1 & 5 & 55 & 30 & 111 & 113 \\
\hline 1994 & & & & & & & & & & & 0 & 56 & 31 & 111 & 117 \\
\hline 1995 & & & 1 & 7 & & & & & & & 8 & 57 & 32 & 119 & 121 \\
\hline 1996 & & & 2 & 17 & & & & & & & 19 & 58 & 33 & 138 & 125 \\
\hline 1997 & & & 5 & & & 1 & & & & & 6 & 59 & 34 & 144 & 129 \\
\hline 1998 & & & & 3 & & & & & & & 3 & 60 & 35 & 147 & 133 \\
\hline 1999 & & & & 1 & & 1 & & & & & 2 & 61 & 36 & 149 & 137 \\
\hline 2000 & & & 2 & & & & & & & & 2 & 62 & 37 & 151 & 141 \\
\hline 2001 & & & 1 & & & & & & & & 1 & 63 & 38 & 152 & 145 \\
\hline 2002 & 1 & & 5 & & & & & & & & 6 & 64 & 39 & 158 & 149 \\
\hline 2003 & & & & & & & & & & & 0 & 65 & 40 & 158 & 153 \\
\hline 2004 & & & & & & & & & & & 0 & 66 & 41 & 158 & 157 \\
\hline 2005 & 2 & & & & & & & & 2 & & 4 & 67 & 42 & 162 & 161 \\
\hline 2006 & & & & & 1 & 1 & & & 3 & & 5 & 68 & 43 & 167 & 165 \\
\hline 2007 & & & & & & & & & 2 & & 2 & 69 & 44 & 169 & 169 \\
\hline
\end{tabular}

Page | 10 
Bio-bibliometric Portrait of B.K Sen

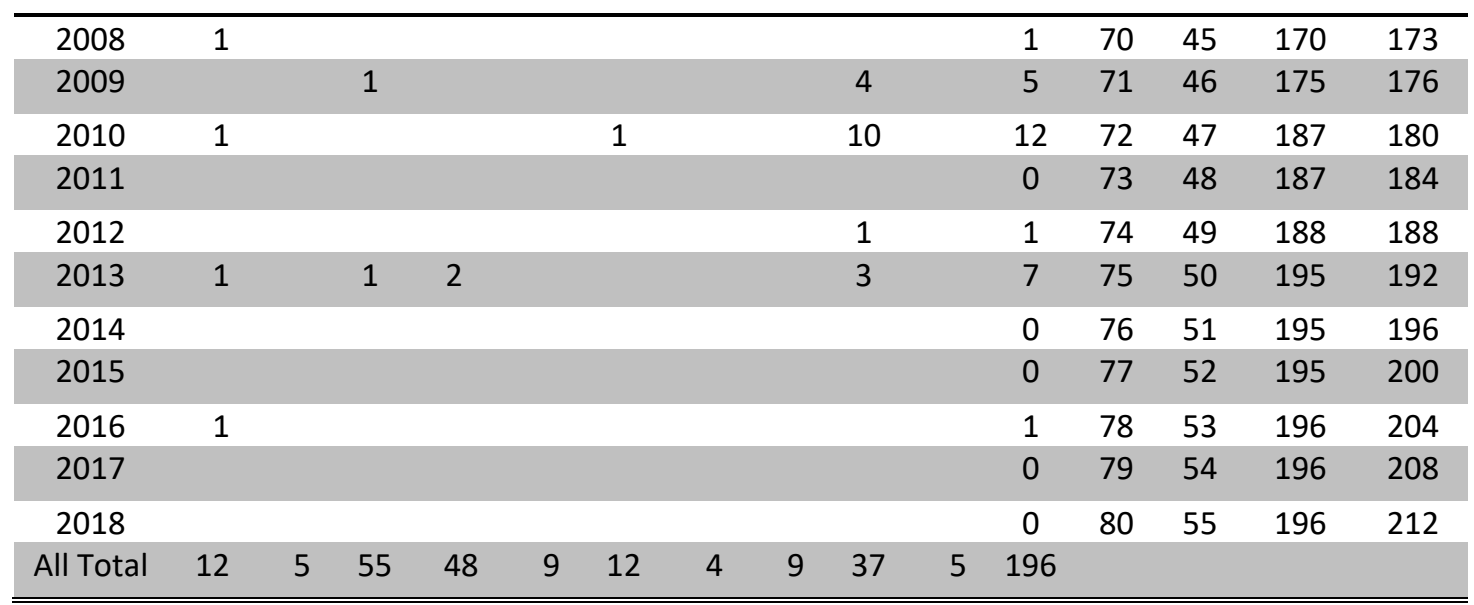

[BK=Book; RVA=Review Articles;TA=Technical \& Popular Articles; WT=Writings on Terminology; $\quad B R=B o o k$ Reviews; $L T=$ Letters; $\quad B L=$ Bibliography; $C T=$ Catalogue; $C M=$ Course Materials; $R P=$ Reports; $A P C=$ Annual Publication Count; $A A=$ Author's Age; PPA=Publication Productivity Age; CAPC=Cumulative Annual Publication Count]

Table 4: Growth of All Publications

\begin{tabular}{|c|c|c|c|c|c|}
\hline Year & APC & AA & PPA & CAPC (Observed) (X) & CAPC (Calculated) (Y) \\
\hline 1964 & 1 & 26 & 1 & 1 & 1.64 \\
\hline 1965 & 4 & 27 & 2 & 5 & 4.21 \\
\hline 1966 & 5 & 28 & 3 & 10 & 7.31 \\
\hline 1967 & 1 & 29 & 4 & 11 & 10.81 \\
\hline 1968 & 5 & 30 & 5 & 16 & 14.64 \\
\hline 1969 & 3 & 31 & 6 & 19 & 18.77 \\
\hline 1970 & 6 & 32 & 7 & 25 & 23.15 \\
\hline 1971 & 4 & 33 & 8 & 29 & 27.76 \\
\hline 1972 & 7 & 34 & 9 & 36 & 32.59 \\
\hline 1973 & 6 & 35 & 10 & 42 & 37.61 \\
\hline 1974 & 3 & 36 & 11 & 45 & 42.82 \\
\hline 1975 & 7 & 37 & 12 & 52 & 48.20 \\
\hline 1976 & 3 & 38 & 13 & 55 & 53.75 \\
\hline 1977 & 7 & 39 & 14 & 62 & 59.46 \\
\hline 1978 & 2 & 40 & 15 & 64 & 65.31 \\
\hline 1979 & 10 & 41 & 16 & 74 & 71.31 \\
\hline 1980 & 5 & 42 & 17 & 79 & 77.44 \\
\hline 1981 & 8 & 43 & 18 & 87 & 83.70 \\
\hline 1982 & 2 & 44 & 19 & 89 & 90.09 \\
\hline 1983 & 2 & 45 & 20 & 91 & 96.61 \\
\hline 1984 & 3 & 46 & 21 & 94 & 103.24 \\
\hline 1985 & 6 & 47 & 22 & 100 & 109.99 \\
\hline 1986 & 4 & 48 & 23 & 104 & 116.85 \\
\hline 1987 & 5 & 49 & 24 & 109 & 123.82 \\
\hline 1988 & 6 & 50 & 25 & 115 & 130.89 \\
\hline 1989 & 5 & 51 & 26 & 120 & 138.07 \\
\hline 1990 & 7 & 52 & 27 & 127 & 145.34 \\
\hline 1991 & 13 & 53 & 28 & 140 & 152.72 \\
\hline 1992 & 13 & 54 & 29 & 153 & 160.19 \\
\hline 1993 & 7 & 55 & 30 & 160 & 167.76 \\
\hline 1995 & 10 & 57 & 32 & 170 & 183.16 \\
\hline 1996 & 28 & 58 & 33 & 198 & 190.99 \\
\hline 1997 & 11 & 59 & 34 & 209 & 198.91 \\
\hline
\end{tabular}


Dutta, $B$.

\begin{tabular}{rrllll}
\hline 1998 & 10 & 60 & 35 & 219 & 206.91 \\
1999 & 5 & 61 & 36 & 224 & 215.00 \\
2000 & 10 & 62 & 37 & 234 & 223.17 \\
2001 & 3 & 63 & 38 & 237 & 231.42 \\
2002 & 12 & 64 & 39 & 249 & 239.75 \\
\hline 2003 & 5 & 65 & 40 & 254 & 248.15 \\
2004 & 2 & 66 & 41 & 256 & 256.63 \\
2005 & 8 & 67 & 42 & 264 & 265.19 \\
2006 & 12 & 68 & 43 & 276 & 273.82 \\
2007 & 9 & 69 & 44 & 285 & 282.52 \\
2008 & 7 & 70 & 45 & 292 & 291.30 \\
2009 & 8 & 71 & 46 & 300 & 300.14 \\
2010 & 17 & 72 & 47 & 317 & 309.06 \\
2011 & 2 & 73 & 48 & 319 & 318.04 \\
2012 & 11 & 74 & 49 & 330 & 327.09 \\
2013 & 17 & 75 & 50 & 347 & 336.21 \\
\hline 2014 & 8 & 76 & 51 & 355 & 345.40 \\
\hline 2015 & 10 & 77 & 52 & 365 & 354.65 \\
2016 & 6 & 78 & 53 & 371 & 363.96 \\
\hline 2017 & 5 & 79 & 54 & 376 & 373.34 \\
2018 & 4 & 80 & 55 & 380 & 382.78 \\
\hline \hline
\end{tabular}

[APC=Annual Publication Count; $A A=$ Author's Age; PPA=Publication Productivity Age; CAPC=Cumulative Annual Publication Count]

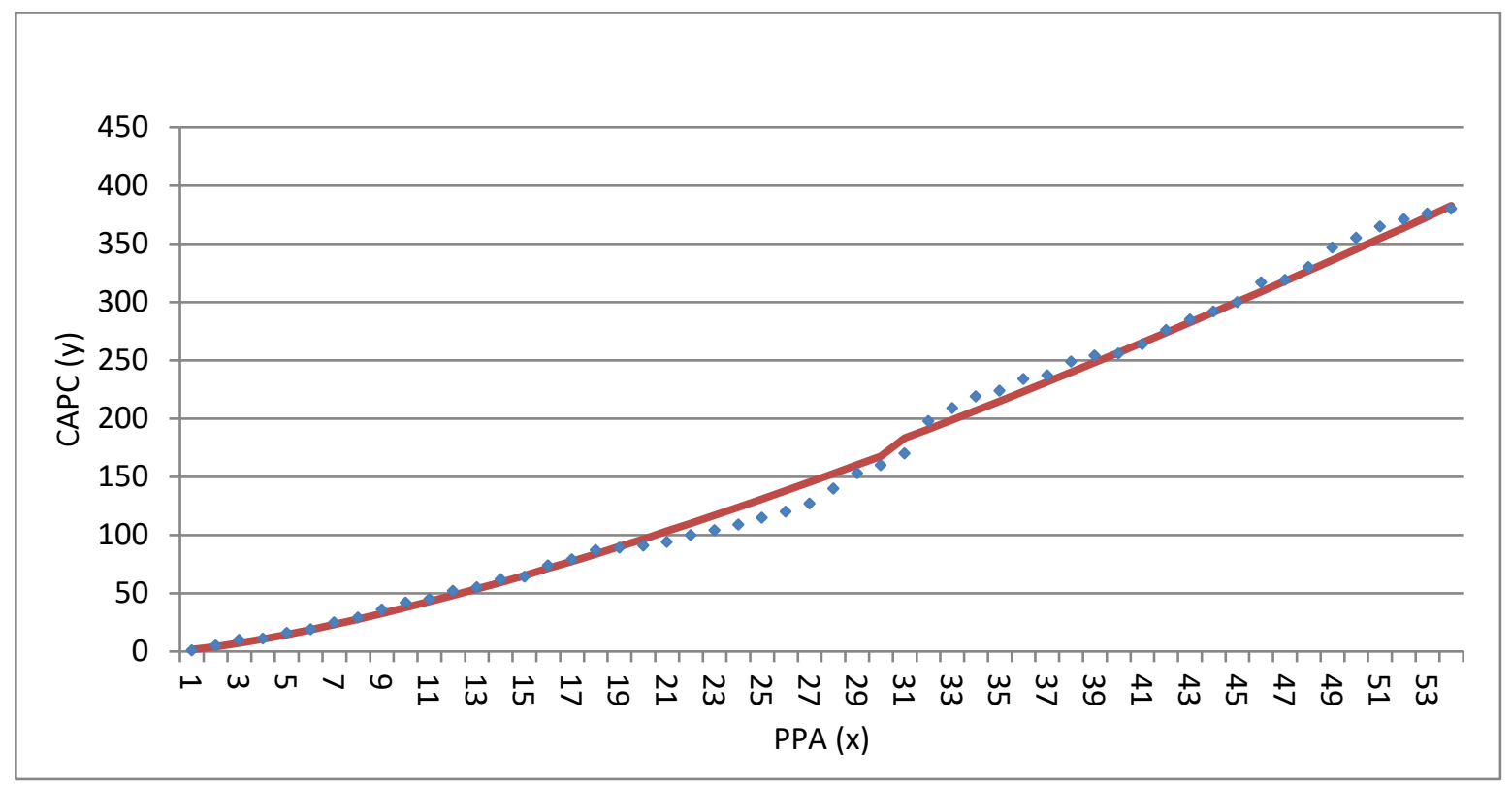

Figure 3: Variation of CAPC with PPA for All Publications 


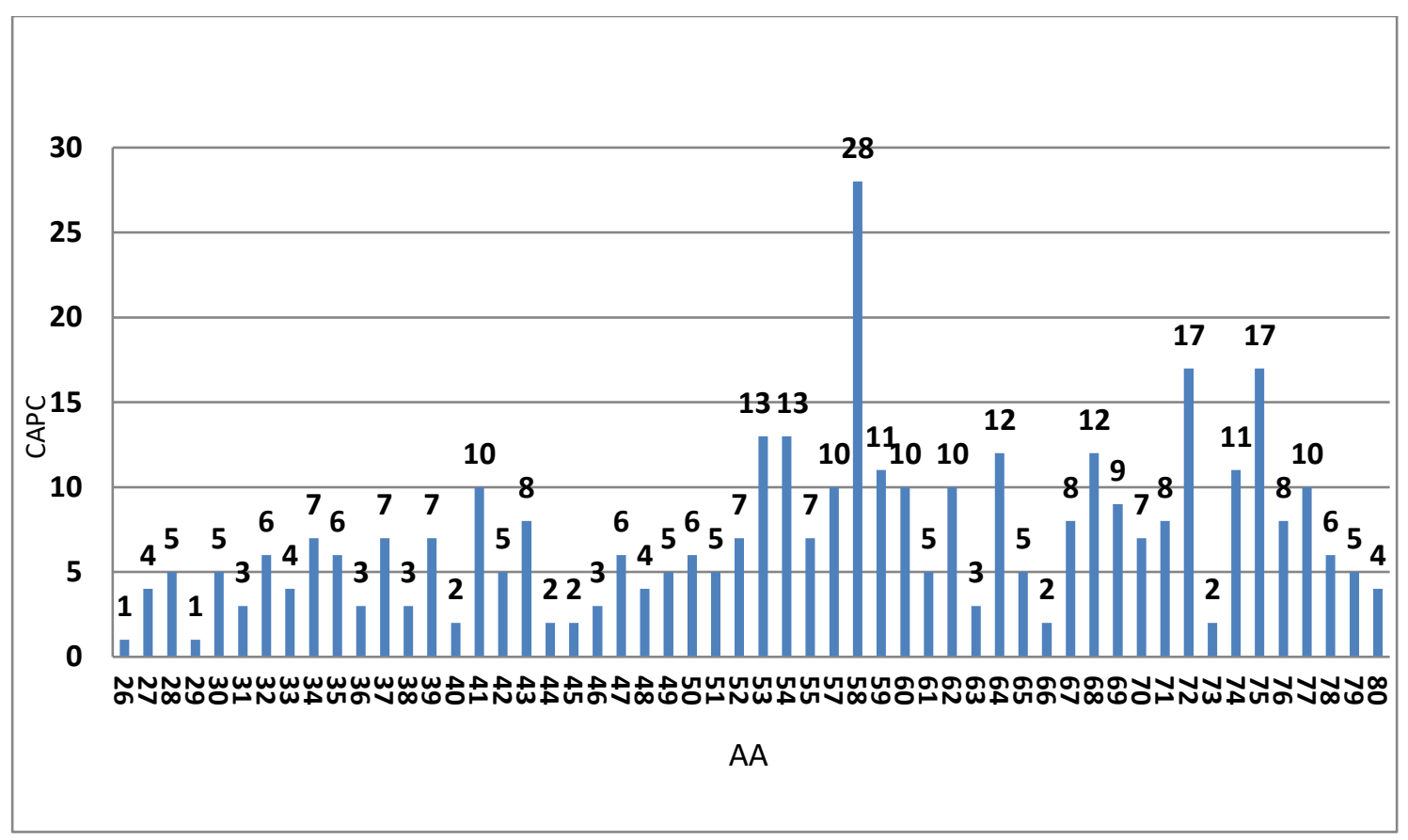

Figure 4: Variation of Number of All Publications (CAPC) with AA

It is observed from Figure 4 that B K Sen contributed a maximum number (28) of scholarly output at the age of fifty eight, i.e. in the year 1996, followed by 17 contributions at the age of 72 and 75 in the years 2010 and 2013. In the years,1991 and 1992 (age 53 and 54) and 2002 and 2006 (age 64 and 68), he contributed 13 papers and 12 papers each respectively. Least number of papers (only one) were contributed in the years 1964 and 1967 (Age 26 and 29). The Quinquennium publication data of $B K$ Sen is presented in Table 5 and Figure 5. The highest contribution figured 59 during 1994 to 1998, at the age-range of 56 to 60 followed by 55 contributions during 2009 to 2013 (age-range 71 to 75) and 45 contributions during 1989 to 1993 (age range 51 to 55). The author was thus most active during the age of 51 to 60 , i.e. since 1989 to 1998. It is worth mentioning that he was a visiting Professor at the University of Malaya, Malaysia during this period. Also, he was potentially active during the age range of 71 to 75 , i.e. since 2009 to 13 . The contribution of B K Sen was least during the age-range of 26 to 30, i.e. since 1964 to 1968 followed by 22 contributions during the agerange of 31 to 35, i.e. since 1969 to 1973 . It is observed that the author's productivity increased with age.

Table 5: Quinquennium Publications

\begin{tabular}{lccc}
\hline Year & AA & PPA & APC \\
\hline $1964-68$ & $26-30$ & $1-5$ & 16 \\
$1969-73$ & $31-35$ & $6-10$ & 26 \\
$1974-78$ & $36-40$ & $11-15$ & 22 \\
$1979-83$ & $41-45$ & $16-20$ & 27 \\
$1984-88$ & $46-50$ & $21-25$ & 24 \\
$1989-93$ & $51-55$ & $26-30$ & 45 \\
$1994-98$ & $56-60$ & $31-35$ & 59 \\
$1999-03$ & $61-65$ & $36-40$ & 35 \\
$2004-08$ & $66-70$ & $41-45$ & 38 \\
$2009-13$ & $71-75$ & $46-50$ & 55 \\
$2014-18$ & $76-80$ & $51-55$ & 33 \\
\hline
\end{tabular}


Dutta, B.

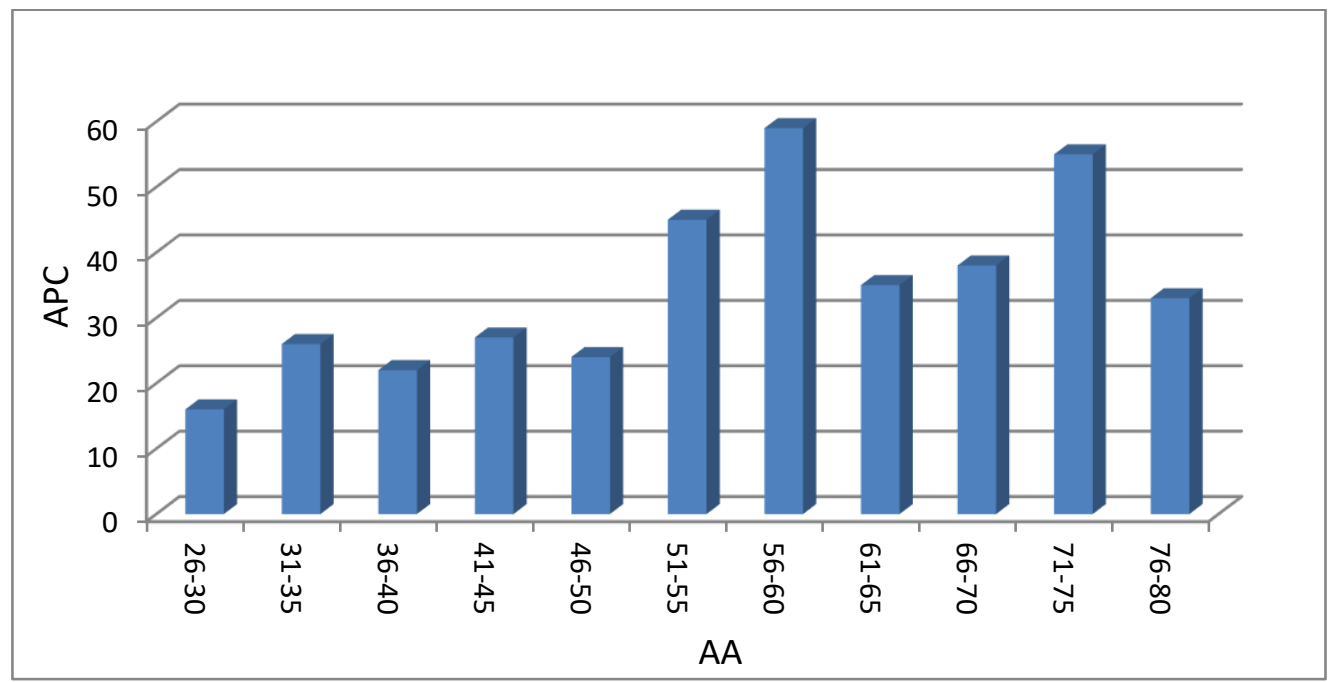

Figure 5: Quinquennium Publications

The total number of publications contributed by B K Sen up to June, 2018 figures 380 , of which research articles amount $184(48 \%)$, followed by technical and popular articles (55, $14 \%)$, writings on terminology $(48,13 \%)$ and course materials $(37,10 \%)$. The remaining $15 \%$ contributions include, books $(12,3 \%)$, letters $(12,3 \%)$, book reviews $(9,2.5 \%)$, catalogue $(9$, $2.5 \%)$, review articles $(5,1.3 \%)$, reports $(5,1.3 \%)$ and bibliography $(4,1 \%)$ (Figure 6$)$.

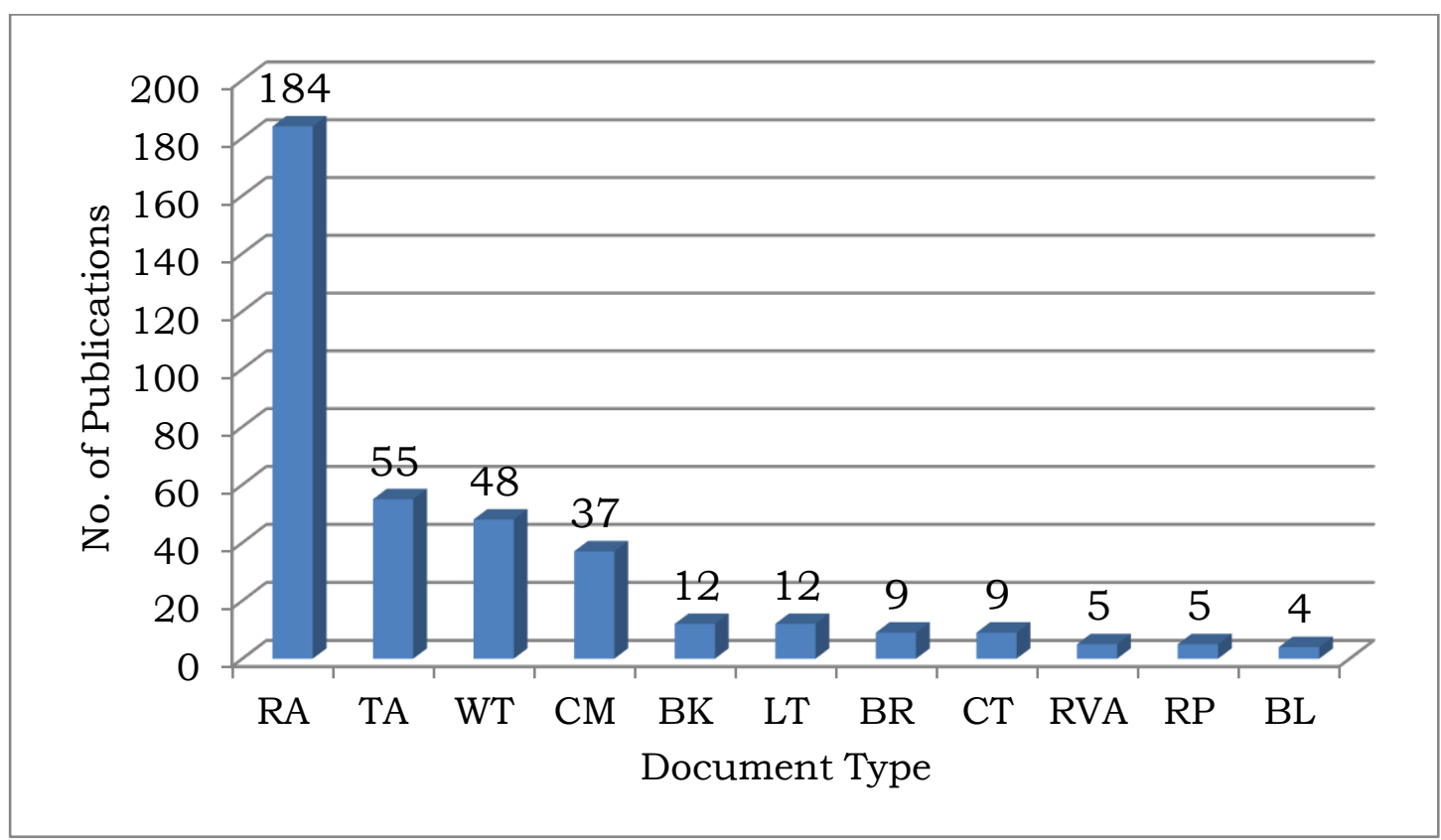

[RA=Research Articles; TA=Technical \& Popular Articles; WT=Writings on Terminology; $C M=$ Course Materials; $B K=$ Book; $L T=L$ Letters; $B R=$ Book Reviews; $C T=$ Catalogue; $R V A=$ Review Articles; $R P=$ Reports; $B L=B$ Bbliography]

Figure 6: Variation of number of Publications with Document Type

\section{Authorship Analysis}

The name of the first authors and the co-authors are enumerated in Table 6. The ranked list of the co-authors is enumerated in Table 7. The top-ranked co-author of B K Sen is A Karanjai 
(co-authored 6 papers in 12 years) followed by B Dutta and S Koley who co-authored 11 papers each over 11 and 17 years. The third and fourth ranked co-authors are A. K. Das and P. P. Ray who contributed 8 and 7 papers respectively during 7 years each.

Table 6: List of First Authors and Co-Authors for Research Articles since 1964 to 2018

\begin{tabular}{|c|c|c|}
\hline Year & $1^{\text {st }}$ Authors' Names & Co-Authors' Names \\
\hline 1964 & T. S. Rajagopalan & T. S. Rajagopalan \\
\hline 1965 & T. S. Rajagopalan & T. S. Rajagopalan, S. Roy, K. L. Gogia \\
\hline 1966 & & J. C. Gera \\
\hline 1975 & B. Guha & R. N. Neogi, S. K. Gupta, S. B. Ghosh, B. Guha \\
\hline 1976 & B. S. Kesavan & B. Guha, K. Ramaswami, B. S. Kesavan \\
\hline 1977 & B. Guha & B. Guha, R. N. Neogi \\
\hline 1985 & H. Bhattacharyya & H. Bhattacharyya \\
\hline 1986 & T. N. Rajan & T. N. Rajan \\
\hline 1989 & & T. A. Pandalai, A. Karanjai, U. M. Munshi \\
\hline 1990 & S. B. Ghosh, U. M. Munshi, Narendra Kumar & S. B. Ghosh, U. M. Munshi, Narendra Kumar \\
\hline 1991 & K. Arora, U. M. Munshi & $\begin{array}{l}\text { Narendra Kumar, K. Arora, U. M. Munshi, A. } \\
\text { Karanjai }\end{array}$ \\
\hline 1992 & A. Karanjai, Narendra Kumar & $\begin{array}{l}\text { A. Karanjai, U. M. Munshi, R. Arora, V. V. Lakshmi, } \\
\text { Narendra Kumar, K.V.S. Prasad }\end{array}$ \\
\hline 1993 & -- & T. A. Pandalai, A. Karanjai \\
\hline 1995 & V. L. Kalyane & V. L. Kalyane, A. Mukhopadhyay \\
\hline 1996 & T. A. Pandalai, V. L. Kalyane & $\begin{array}{l}\text { T. A. Pandalai, A. Karanjai, V. L. Kalyane, A. N. } \\
\text { Zainab, Che Azlan bin Taib, Mohd. Faris, Yaacob M }\end{array}$ \\
\hline 1997 & U. M. Munshi, Kiran Kaur & U. M. Munshi, Kiran Kaur, Lily Lee, Tiew Wai Sin, \\
\hline 1998 & V. L. Kalyane & $\begin{array}{l}\text { Khong Wye Keen, Lee Soo Hoon, Lim Bee Ling, Md } \\
\text { Rafae Abdullah, Ting Chang } \\
\text { Nguam, Wee Siu Hang, V. L. Kalyane, T. A. Pandalai, } \\
\text { A. Karanjai }\end{array}$ \\
\hline 1999 & W. S. Tiew & W. S. Tiew \\
\hline 2000 & A. K. Das, B. Dutta & A. K. Das, B. Dutta \\
\hline 2001 & B. Dutta & B. Dutta, A. K. Das, U. M. Munshi \\
\hline 2002 & B. Dutta, V. L. Kalyane & B. Dutta, A. K. Das, V. L. Kalyane \\
\hline 2003 & B. C. Biswas, V. L. Kalyane, S. Koley & $\begin{array}{l}\text { B. C. Biswas, V. L. Kalyane, S. Koley, K. Chatterjee, } \\
\text { A. Karanjai }\end{array}$ \\
\hline 2005 & A. K. Das, B. Dutta, P. P. Ray & A. K. Das, B. Dutta, P. P. Ray, C. Dutta, B. C. Biswas \\
\hline 2006 & S. Chakraborty, S. Koley, B. C. Biswas & $\begin{array}{l}\text { S. Chakraborty, S. Koley, B. C. Biswas, A. K. Das, C. } \\
\text { Saha }\end{array}$ \\
\hline 2007 & $\begin{array}{l}\text { A. K. Das, B. C. Biswas, P. P. Ray, V. K. J. } \\
\text { Jeevan }\end{array}$ & $\begin{array}{l}\text { A. K. Das, B. C. Biswas, P. P. Ray, V. K. J. Jeevan, C. } \\
\text { Dutta, A. Roy }\end{array}$ \\
\hline 2008 & S. Mallik, B. Dutta, A. K. Das & $\begin{array}{l}\text { S. Mallik, B. Dutta, A. K. Das, K. P. Majumder, C. } \\
\text { Dutta }\end{array}$ \\
\hline 2009 & B. Dutta & B. Dutta, K. P. Majumder \\
\hline 2010 & Tilak Hazarika, B. Dutta & $\begin{array}{l}\text { Tilak Hazarika, B. Dutta, K. P. Majumder, Deepak } \\
\text { Sharma }\end{array}$ \\
\hline 2011 & B. Dutta & B. Dutta \\
\hline 2012 & P. P. Ray, R. Giri & P. P. Ray, R. Giri, B. C. Biswas, P. Chand \\
\hline 2013 & B. Dutta, R. Giri, Sangeeta Narang, S. Koley & $\begin{array}{l}\text { B. Dutta, R. Giri, Sangeeta Narang, S. Koley, K. P. } \\
\text { Majumder, Archana Shukla }\end{array}$ \\
\hline 2014 & S. Koley, Sarmistha Mitra, B. Dutta & S. Koley, Sarmistha Mitra, B. Dutta, Archana Shukla \\
\hline 2015 & $\begin{array}{l}\text { S. Koley, P. P. Ray, B. Dutta, S. Narang, R. } \\
\text { Giri }\end{array}$ & $\begin{array}{l}\text { S. Koley, P. P. Ray, B. Dutta, S. Narang, R. Giri, K. P. } \\
\text { Majumder, Archana Shukla, G. mahesh }\end{array}$ \\
\hline 2016 & P. P. Ray, H. K. Tripathi, S. Koley & P. P. Ray, H. K. Tripathi, S. Koley, \\
\hline 2017 & V. K. J. Jeevan & V. K. J. Jeevan \\
\hline 2018 & S. Koley & S. Koley \\
\hline
\end{tabular}


Dutta, $B$.

Table 7: Ranking of Co-Authors

\begin{tabular}{|c|c|c|c|c|}
\hline Rank & $\begin{array}{l}\text { No. of Papers } \\
\text { Contributed with } \\
\text { B. K. Sen (P) }\end{array}$ & Co-Authors' Names & $\begin{array}{c}\text { No. of } \\
\text { Contributing } \\
\text { Years (Y) }\end{array}$ & $P / Y$ \\
\hline 1 & 12 & A. Karanjai & 6 & 2 \\
\hline 2 & 11 & B. Dutta, S. Koley & 11,17 & $1,0.65$ \\
\hline 3 & 8 & A. K. Das & 7 & 1.14 \\
\hline 4 & 7 & P. P. Ray & 7 & 1 \\
\hline 5 & 6 & $\begin{array}{l}\text { B. C. Biswas, B. Guha, R. N. Neogi, T. A. Pandalai, U. } \\
\text { M. Munshi }\end{array}$ & $5,3,2,3,6$ & $\begin{array}{l}1.2,2,3 \\
2,1\end{array}$ \\
\hline 6 & 5 & K. P. Majumder, V. L. Kalyane & 5,4 & $1,1.3$ \\
\hline 7 & 3 & $\begin{array}{l}\text { Archana Shukla, C. Dutta, N. Kumar, R. Giri, T. S. } \\
\text { Rajagopalan }\end{array}$ & $3,3,3,3,2$ & $\begin{array}{c}1,1,1 \\
1.5\end{array}$ \\
\hline 8 & 2 & S. B. Ghosh, S. Narang, V. K. J. Jeevan & $2,2,2$ & $1,1,1$ \\
\hline 9 & 1 & $\begin{array}{l}\text { A. Mukhopadhyay, A. N. Zainab, A. Roy, B. S. } \\
\text { Kesavan, C. Saha, Che A. B. Taib, D. Sharma, G. } \\
\text { Mahesh, H. Bhattacharyya, H. K. Tripathi, J. C. Gera, } \\
\text { K. Arora, K. Chatterjee, K. L. Gogia, K. Ramaswami, } \\
\text { K.V.S. Prasad, Khong W. Keen, K. Kaur, L. S. Hoon, } \\
\text { Lily Lee, L. B. Ling, Md R. Abdullah, Mohd. Faris, P. } \\
\text { Chand, R. Arora, S. Chakraborty, S. K. Gupta, S. } \\
\text { Mallik, S. Roy, S. Mitra, T. N. Rajan, Tiew W. Sin, T. } \\
\text { Hazarika, T. Chang, V. V. Lakshmi, } \\
\text { W. S. Tiew, Yaacob M }\end{array}$ & 1 each & $\begin{array}{l}1 \text { (For all } \\
\text { authors) }\end{array}$ \\
\hline
\end{tabular}

\section{Co-authorship and Lotka's Law}

Lotka's law describes the publication-frequency of authors in a given subject field. It states that the number of authors making contributions is about $1 / \mathrm{n}^{2}$ of those making one; and the proportion of all contributors, that make a single contribution, is about 60 percent. This means that out of all the authors in a given field, 60 percent will have just one publication, and 15 percent will have two publications $\left(1 / 2^{2}\right.$ times of 60$)$. Seven percent authors will have three publications $\left(1 / 3^{2}\right.$ times of 60$)$, and so on. According to Lotka's law of scientific productivity, only six percent of the authors in a field will produce more than 10 articles. Lotka's law, when applied to large bodies of literature over a fairly long period of time, can be accurate in general, but not statistically exact. The general form of Lotka's law can be expressed as $y=c / x^{n}$ where $y=$ percentage of authors, $x=$ number of articles published by an author, $\mathrm{c}=$ constant and $-\mathrm{n}=\mathrm{s}$ lope of the log-log plot. In this co-authorship analysis, there are 61 co-authors of Sen, of which 39 co-authors (63\%) were associated with single article, 3 coauthors were $(5 \%)$, were associated with two articles, 5 co-authors were $(8.2 \%)$ were associated with three articles and so on. The co-authorship data thus nearly tallies Lotka's Law. The Lotka's equation for this co-authorship data is found as: $Y=45 /(X)^{0.9}$, where $Y=$ Cumulative no. of co-authors and $\mathrm{X}=$ Cumulative no. of articles.

\section{Degree of Collaboration}

The Degree of Collaboration (DC) is defined as the ratio between multi-authored publications (MAP) to annual publication count (APC). If no single-authored publication comes in any year, then APC will be equal to MAP. It is observed that, during 54 years of writing span of the author, the DC had its maximum value (1) only in 13 numbers of years, i.e. no single-authored publications of the Author came out in these 13 years (Table 8). The DC values lied between 0.5 and 1 for 8 years, the same was equal to 0.5 for 6 years and less than 0.5 for 8 years. The Degree of Collaboration was zero for 5 years, i.e. in these 5 years only single-authored publications of the Author came out. 
Table 8: Variation of Degree of Collaboration over the Years

\begin{tabular}{ccc}
\hline \hline DC Values & \multicolumn{1}{c}{ Years } & No. of years \\
\hline \hline$=1$ & '65, '66, '75, '76, '77, '86, '89, '93, '95, '01, '02, '03 \& '05 & 13 \\
$>0.5 \&<1$ & $' 90$, '92, '96, '98, '2K, '06, '07, '16 & 8 \\
$=0.5$ & $' 85,{ }^{\prime}$ '08, '11, '12, '14, '15 & 6 \\
$<0.5$ & '91, '97, '99, '09, '10, '13, '17, '18 & 8 \\
$=0$ & '69, '78, '87, '88, '04 & 5 \\
\hline \hline
\end{tabular}

\section{Communication Channels and Ranking of Articles}

The distribution of research articles over journals show highly skewed pattern as evident from Table 9, which shows that 33 percent of all articles (61) were published in Annals of Library and Information Studies followed by Malaysian journal of Library and Information Science (17 articles, 9\%) and Library Herald (10 articles, 5.4\%). Other remarkable journals that published Sen's articles are, Journal of Documentation, Scientometrics, Current Science, and SRELS Journal of Information Management. The article entitled "Documentation note: Normalized Impact Factor" ranked one at per Web of Science (47 citations), Scopus (41 citations) and Google Scholar (91 citations) (Table 10). The rankings of top 10 articles at per Web of Science, Scopus and Google Scholar are furnished in Table 10. The Citation Growth Rate of these 27 articles, i.e. times cited per unit age of the articles are also listed here.

Table 9: Communication Channels (Journals) of B K Sen

\begin{tabular}{lr}
\hline \hline \multicolumn{1}{c}{ Journal Name with Abbreviation } & $\begin{array}{c}\text { Frequency of } \\
\text { Publication with \% }\end{array}$ \\
\hline \hline Annals of Library and Information Studies (ALIS) & $61(33.2 \%)$ \\
Malaysian Journal of Library \& Information Science (MJLIS) & $17(9.2 \%)$ \\
Library Herald (LH) & $10(5.4 \%)$ \\
ILA Bulletin (ILA) & $9(4.9 \%)$ \\
IASLIC Bulletin (IASLIC), SRELS Journal of Information Management & $6(3.3 \%)$ \\
(SRELS) & $5(2.7 \%)$ \\
Indian Journal of History of Science (IJHS) & $4(2.2 \%)$ \\
Journal of Documentation (JDOC) & $2(1.1 \%)$ \\
Current Science (CS), Jnan Bichitra (JB), Scientometrics (SCI), DESIDOC & \\
Journal of Library and Information Technology (DJLIT) & $19(10.3 \%)$ \\
Other Journals (OTH) & $39(21.2 \%)$ \\
Papers presented in National and International Seminars and & \\
Conferences along with published in Proceedings (Sem/ Conf) & \\
\hline \hline
\end{tabular}

\section{Core Journals and Bradford's Law}

The total number of research articles contributed by Sen figured 184, of which 61 (33.2\%, i.e. one-third) articles were published by Annals of Library and Information Studies. This is the core communication channel of Sen. In the allied zone, 57 articles were published in 7 journals and in the alien zone there are 23 journals and around 25 Seminars and Conferences, which figures 48 . The ratio of number of communication channels is figured out as, 1:7:48, $(1: n: n)^{2}$. The distribution of journals is thus in well tune with Bradford's Law.

\section{Scientometric Indicators}

The scientometric indicators of Sen are calculated on the basis of citation data available from Web of Science, Scopus and Google Scholar. The number of citations received by Sen is 1183 (Google Scholar), 291 (Web of Science) and 185 (Scopus). The Google Scholar statistics outshines other two database statistics. The values of h-index are 8 (Scopus and Web of 
Dutta, B.

Science) and 19 (Google Scholar). The Recency Index of Sen is nearly 0.4 at per the three databases, i.e. nearly 40 percent of the total number of citations received by Sen was appended during last five years (2013-18). The relevance of Sen's research has been found increasing with time (Table 11). The citation pattern indicates trifle chance of obsolescence of Sen's works in near future.

Table 10: Ranking of Papers by Number of Citations Received

\begin{tabular}{|c|c|c|c|c|c|c|c|c|c|c|c|}
\hline \multirow[t]{2}{*}{ Title of the Paper } & \multirow{2}{*}{ 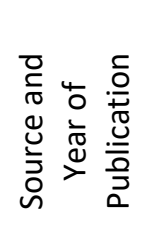 } & \multicolumn{3}{|c|}{$\begin{array}{c}\text { Times Cited (TC) } \\
\text { at per } \\
\end{array}$} & \multicolumn{3}{|c|}{ Rank at per } & \multirow{2}{*}{ 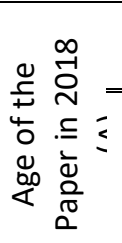 } & \multicolumn{3}{|c|}{$\begin{array}{l}\text { Citation Growth Rate } \\
\text { (CGR) at per (TC/A) }\end{array}$} \\
\hline & & 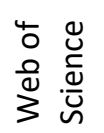 & 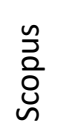 & 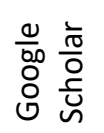 & 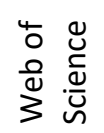 & $\frac{n}{0}$ & 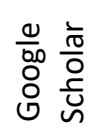 & & 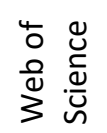 & 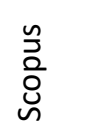 & $\begin{array}{l}\frac{1}{00} \\
0 \\
0 \\
0 \\
0 \\
0 \\
\end{array}$ \\
\hline $\begin{array}{l}\text { 1) Documentation note: } \\
\text { Normalized Impact Factor }\end{array}$ & $\begin{array}{l}\text { JDOC/ } \\
1992\end{array}$ & 47 & 41 & 91 & 1 & 1 & 1 & 26 & 1.8 & 1.6 & 3.5 \\
\hline $\begin{array}{l}\text { 2) A method for determining } \\
\text { the Impact Factor of a non- } \\
\mathrm{SCl} \text { journal }\end{array}$ & $\begin{array}{l}\text { JDOC } / 19 \\
89\end{array}$ & 19 & --- & 34 & 2 & -- & 11 & 29 & 0.66 & --- & 1.2 \\
\hline $\begin{array}{l}\text { 3) Acknowledgement } \\
\text { patterns in research articles: } \\
\text {...... }\end{array}$ & $\begin{array}{l}\text { MJLIS/ } \\
2002\end{array}$ & 16 & 10 & 26 & 3 & 7 & 14 & 16 & 1 & 0.63 & 1.63 \\
\hline $\begin{array}{l}\text { 4) Economic botany: a } \\
\text { bibliometric study }\end{array}$ & $\begin{array}{l}\text { MJLIS/ } \\
2007\end{array}$ & 10 & 17 & 43 & 4 & 3 & 8 & 11 & 0.91 & 1.55 & 3.91 \\
\hline $\begin{array}{l}\text { 5) Scientometric portrait of } \\
\text { Nobel laureate Pierre-Gilles } \\
\text { de Gennes }\end{array}$ & $\begin{array}{l}\text { MJLIS/ } \\
1996\end{array}$ & 10 & 18 & 65 & 4 & 2 & 3 & 22 & 0.45 & 0.82 & 2.95 \\
\hline $\begin{array}{l}\text { 6) Indian periodicals in the } \\
\text { Science-Citation-Index }\end{array}$ & $\begin{array}{l}\mathrm{SCl} / \\
1992\end{array}$ & 9 & 12 & 26 & 5 & 6 & 14 & 26 & 0.35 & 0.46 & 1 \\
\hline $\begin{array}{l}\text { 7) Evaluation of recent } \\
\text { scientific-research output by } \\
\text { a bibliometric method }\end{array}$ & $\begin{array}{l}\mathrm{SCl} / \\
1992\end{array}$ & 9 & 13 & 36 & 5 & 5 & 10 & 26 & 0.35 & 0.5 & 1.38 \\
\hline $\begin{array}{l}\text { 8) Scientometric portrait of C } \\
\text { R Bhatia, an Indian geneticist } \\
\text { and plant breeder }\end{array}$ & $\begin{array}{l}\text { MJLIS/ } \\
1998\end{array}$ & 8 & --- & 58 & 6 & --- & 5 & 20 & 0.4 & --- & 2.9 \\
\hline $\begin{array}{l}\text { 9) Symbols and formulas for } \\
\text { a few bibliometric concepts }\end{array}$ & $\begin{array}{l}\text { JDOC/ } \\
1999\end{array}$ & 8 & 12 & 26 & 6 & 6 & 14 & 19 & 0.42 & 0.63 & 1.37 \\
\hline $\begin{array}{l}\text { 10) Library and Information } \\
\text { science literature and Lotka's } \\
\text { law }\end{array}$ & $\begin{array}{l}\text { MJLIS/ } \\
1996\end{array}$ & 7 & 16 & 27 & 7 & 4 & 13 & 22 & 0.32 & 0.73 & 1.23 \\
\hline
\end{tabular}

Table 11: Different Scientometric Indicators of B. K. Sen

\begin{tabular}{|c|c|c|c|c|c|c|c|c|c|c|c|c|}
\hline $\begin{array}{l}\text { Citation } \\
\text { Databases }\end{array}$ & $\begin{array}{c}\text { Total no. of } \\
\text { citations } \\
\text { received till } \\
\text { date }[C(T o t)]\end{array}$ & $\begin{array}{l}\text { Total no. of } \\
\text { citations } \\
\text { received } \\
\text { during last } 5 \\
\text { years [C(5)] }\end{array}$ & 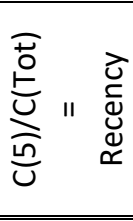 & 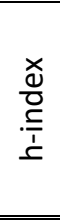 & $\begin{array}{c}\text { Excess } \\
\text { Citation } \\
(E C) \\
{[C(T o t)-} \\
\left.h^{2}\right] \\
\end{array}$ & 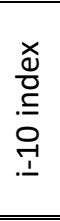 & 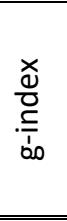 & 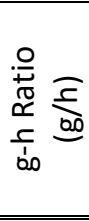 & 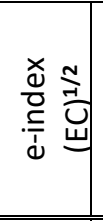 & 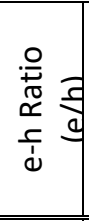 & 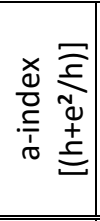 & 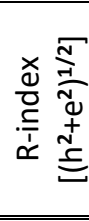 \\
\hline Scopus & 185 & 66 & 0.36 & 8 & 121 & 8 & 12 & 1.5 & 11 & 1.4 & 23.1 & 13.6 \\
\hline Web of Sci & 291 & 104 & 0.36 & 8 & 227 & 5 & 12 & 1.5 & 15 & 1.9 & 36.1 & 17.0 \\
\hline Google Scholar & 1183 & 445 & 0.38 & 19 & 822 & 29 & 31 & 1.6 & 28.7 & 1.5 & 62.4 & 34.4 \\
\hline
\end{tabular}




\section{CONCLUSION}

This study highlights the major aspects of the career of the Indianinformation scientistBimal Kanti Sen. Similar studies on prominent scientometricians include Eugene Garfield, Tibor Braun, Mike Thelwall and V.L. Kalyane, have been obvious in the literature. The scholar, Dr. Bimal Kanti Sen is the second Indian figure to be considered for a biobioliometric study besides Kalyane. He contributed 390 writings since 1964 to 2018, i.e. during 55 years ofhis service periodplus retirement period. He authored seven writings per year on an average. Of the 390 writings, he contributed about three research articles per year consistently over the entire career period. His academic and research activity steadily increased with his age. His most notable research works wasnormalization of Impact Factor and finding Impact Factor of non-SCl journal. His other notable works include biobibliometrics analysis, history of science, lexicography etc. He is still academically very active and continuously adding research contributions.Biobibliometric studies help to analyse profiles of individual scientists over the years that enables identification of the knowledge generation and development cycle at different phases. Also, consolidated studies of numbers of individual contemporaries and individuals of different era are necessary to find out impact analysis of a subject at times. This study extends similar attempts for both global and Indian LISand scientometric domains.

\section{ACKNOWLEDGEMENT}

The biographical information and publications are collected from and also verified by B. K. Sen. The cooperation is hereby thankfully acknowledged.

\section{REFERENCES}

Angadi, M., Koganuramath, M. M., Kademani, B. S., Kumbar, B. D. and Jange, S. 2006. Nobel laureate Anthony J Leggett: A scientometric portrait. SRELS Journal of Information Management, Vol.43, no.4: 363-374.

Angadi, M., Koganuramath, M. M., Kademani, B. S., Kalyane, V. L. and Sen, B. K. 2004. Scientometric portrait of Nobel laureate Leland H. Hartwell, In H. Kretschmer, Y. Singh, \& R. Kundra (eds.) WIS-2004, International Workshop on Webometrics, Informetrics and Scientometrics, (2-5 March, 2004); (pp. 10-30), Organised by Society for Information Science, New Delhi, and Indian Institute of Technology. Available at: http://eprints.rclis.org/archive/00001442/.

Hazarika, T., Sarma, D. and Sen, B. K. 2010. Scientometric portrait of Nayana Nanda Borthakur: a biometeorologist. Annals of Library and Information Studies, Vol. 57, no.1: 21-32.

Hertzel, D. H. 1987. Bibliometrics, history of the development of ideas, In. A. Kent, ed. Encyclopedia of Library and Information Science, New York: Marcel Dekker, 1987: 144219.

Kademani, B. S.and Kalyane, V. L. 1998. Scientometric portrait of R. Chidambaram: The Indian nuclear physicist, based on citation analysis. Kelpro Bulletin, Vol.2, no.1: 13-29.

Kademani, B. S., Kalyane, V. L. andVijai Kumar. 2000. Scientometric portrait of Vikram Ambalal Sarabhai: A citation analysis. SRELS Journal of Information Management, Vol.37, no.2: 107-132.

Kademani, B. S., Kalyane, V. L. and Balakrishnan, M. R. 1994. Scientometric portrait of PK Iyengar. Library Science, Vol.31, no.4: 155-176. 
Dutta, B.

Kademani, B. S., Kalyane, V. L.and Kademani, A. B. 1994. Scientometric Portrait of Nobel Laureate Dr. CV Raman. Indian Journal of Information Library and Society, Vol.7, no.3-4: 215-249.

Kademani, B. S., Kalyane, V. L. and Kademani, A. B. 1996. Scientometric portrait of Nobel Laureate S. Chandrasekhar. JISSI: The International Journal of Scientometrics and Informetrics, Vol.2, no.2-3: 119-135.

Kademani, B. S., Kalyane, V. L. and Kademani, A. B. 1996. Scientometric Portrait of Sir KS Krishnan. Indian Journal of Information, Library and Society, Vol.9, no.1-2: 125-150.

Kademani, B. S., Kalyane, V. L. and Kumar, V. 2001. Scientometric portrait of Nobel Laureate Ahmed Hassan Zewail. Malaysian Journal of Library \& Information Science, Vol.6, no.2: 53-70.

Kademani, B. S., Kalyane, V. L. and Kumar, V. 2002. AH Zewail: Research collaborator par excellence. Scientometrics, Vol.53, no.1: 113-121.

Kademani, B. S., Kalyane, V. L. and Kumar, V. 2002. Scientometric portrait of Nobel Laureate Harold W. Kroto. SRELS Journal of Information Management, Vol.39, no.4: 409434.

Kademani, B. S., Kalyane, V. L., Kumar, V. and Mohan, L. 2005. Nobel Laureates: Their publication productivity, collaboration and authorship status. Scientometrics, Vol.62, no.2: 261-268.

Kademani, B., Kalyane, V. and Jange, S. 1999. Scientometric portrait of Nobel Laureate Dorothy Crowfoot Hodgkin. Scientometrics, Vol.45, no.2: 233-250.

Kalyane, V. L. 1995. Scientometric portrait of PM Bhargava. Lucknow Librarian, Vol.27, no.14: 42-70.

Kalyane, V. L. 2004. Scientometric portrait of L L Narayana, In:Knowledge Societies and Libraries: Papers in Honour of Prof. A.A.N. Raju, New Delh: Ess Ess Publishers: 362-388.

Kalyane, V. L. and Devarai Rajashekhar, S. 1994. Informetrics on CS Venkata Ram, In: New Horizons in Library and Information Science: Dr. Velaga Venkatappaiah Festschrift, eds: CP Vashishth, LS Ramaiah, NV Jagga Rao and TV Prafulla Chandra, Madras: TR Pub: 475478.

Kalyane, V. L. and Kademani, B. S. 1995. Scientometric portrait of R. Chidambaram: A publication productivity analysis. Journal of Information Sciences, Vol.5, no.3: 101-140.

Kalyane, V. L. and Kademani, B. S. 1997. Scientometric portrait of Barbara McClintock: The Nobel Laureate in physiology. Kelpro Bulletin, Vol.1, no.1: 3-14.

Kalyane, V. L. and Kalyane, S. V. 1993. Scientometric Portrait of Vinodini Reddy. Journal of Information Sciences, Vol.4, no.1: 25-47.

Kalyane, V. L. and Kalyane, S. V. 1994. Scientometric portrait of MS Swaminathan. Library Science, Vol.31, no.1: 31-46.

Kalyane, V. L. and Munnolli, S. S. 1995. Scientometric portrait of TS West. Scientometrics, Vol.33, no.2: 233-256.

Kalyane, V. L., Prakasan, E. R. and Vijay Kumar. 2001. Scientometric Portrait of Ranjit Kumar Mitra. ILA Bulletin, Vol.37, no.2: 39-53.

Kalyane, V. L.and Samanta, R. K. 1995. Informetrics on K. Ramiah. In: New vistas in library and information science: Papers in honour of Professor GVSL Narasimha Raju: 565-578.

Kalyane, V. L. and Sen, B. K. 1996. Scientometric Portrait of Nobel Laureate Pierre-Gilles de Gennes. Malaysian Journal of Library \& Information Science,Vol.1, no.2: 13-26.

Kalyane, V. L. and Sen, B. K. 1998. Scientometric portrait of CR Bhatia, an Indian geneticist and plant breeder. Malaysian Journal of Library \& Information Science, Vol.3, no.1: 2542.

Kalyane, V.L. and Sen, B. K. 2003. Research productivity of Tibor Braun: An analytical chemist-cum-scientometrician. Annals of Library and Information Studies, Vol.50, no.2: 47-61. 
Koganuramah, M. M., Angadi, M., Kalyane, V. L. and Jange, S. 2004. Physics Nobel Laureate Wolfgang Ketterle: a scientometric portrait. Malaysian Journal of Library \& Information Science, Vol. 9, no.2: 35-61.

Koley, S. and Sen, B. K. 2006. A biobibliometric study on Prof. BN Koley, an eminent physiologist. Annals of Library and Information Studies, Vol.53, no.2: 74-82.

Koley S and Sen B. K. 2014a. An Enigmatic beauty: Suchitra Sen's feminine charm and emotive force contributed to her illusive imagery, Prabashi Post (2014, November 29). Available at: http:// www.Prabashipost.com/b-179-suchitra.aspx.

Koley S. and Sen B. K. 2014b. Biobibliometric study on Dr. Sambhu Nath De: A pioneer in cholera research. Library Herald, Vol.52, no.1: 28-39.

Koley S. and Sen B. K. 2016a. Biobibliometric study of Professor A. S. Paintal, a celebrated medical physiologist. Library Herald, Vol. 54, no.2: 174-190.

Koley, S. and Sen, B. K. 2016b. Biobibliometric portrait of VL Kalyane, a stellar biobibliometrician. Annals of Library and Information Studies, Vol.63, no.3: 161-175.

Koley, S. and Sen, B. K. 2018. Biobibliometric portrait of the astronomer Jan Hendrik Oort. Annals of Library and Information Studies, Vol.64, no.4: 217-228.

Munnolli, S. S. and Kalyane, V. L. 2003. Scientometric Portrait of Ram Gopal Rastogi. Annals of Library and Information Studies, Vol.50, no.1: 1-17.

Munnolli, S. S., Pujar, S. M. and Kademani, B. S. 2011. Scientometric Portrait of Nobel Laureate Harald zur Hausen. Annals of Library and Information Studies, Vol.58, no.1: 7178.

Parvathamma, N. and Gobbur, D. S. 2008. TM Aminabhavi: A biobibliometric study. Annals of Library and Information Studies, Vol. 55, no.2: 127-134.

Price D J, 1963. Little Science, Big Science and Beyond. Columbia University Press

Sangam, S. L., Savanur, K., Manjunath, M. and Vasudevan, R. 2006. Scientometric portrait of Prof. Peter John Wyllie. Scientometrics, Vol.66, no.1: 43-53.

Sangam, S. L.and Savanur, K. P. 2006. Dr. N. Rudraiah: A biobibliometric study. SRELS Journal of Information Management, Vol.43, no.2: 185-199.

Sangam, S., Savanur, K.and Manjunath, M. 2007. Communication and collaborative research pattern of Sivaraj Ramaseshan: A scientometric portrait. Scientometrics, Vol.71, no.2: 217-230.

Sangam, S. L. and Savanur, K. 2010. Eugene Garfield: A scientometric portrait. Collnet Journal of Scientometrics and Information Management, Vol.4, no.1: 41-51.

Sen, B. K. and Karanjai, A. 2003. Dr. Biman Bagchi a bibliometric portrait. All India Conference of IASLIC, $24^{\text {th }}$, Knowledge management in special libraries in digital environment: 437446, Dehra Dun.

Sen, S. K. and Gan, S. K. 1990. Biobibliometrics: Concept and application in the study of productivity of scientists. International Forum on Information and Documentation, Vol.15, no.3: 13-21.

Stockley, W. 1957. On the statistics of individual variations of productivity in research laboratories. Proceedings of the Institute of Radio Engineers, 279-290. Available at: https://www.gwern.net/docs/iq/1957-shockley.pdf.

Tiew, W. S. 1999. Khoo Kay Kim, professor of Malaysian history: A biobibliometric study. Malaysian Journal of Library \& Information Science, Vol.4, no.2: 47-57.

Vellaichamy, A. and Amsan, E. 2016. Scientometric portrait of Mike Thelwall. Library Philosophy and Practice, 1487. Available at: http://digitalcommons.unl.edu/ libphilprac/1487. 